\title{
Association of clinical features of typhoid fever with socioeconomic status in Pakistan
}

Muhammad Samsoor Zarak, ${ }_{1}^{1}$ Hamaiyal Sana, ${ }^{2}$ Muzhgan Shah, ${ }^{2}$ Shabir Lehri, ${ }^{2}$ Mahekan Saghir, ${ }^{2}$ Qandeel Gul, ${ }^{2}$ Muhammad Saood, ${ }^{3}$ Aqeel Nasim ${ }^{3}$ and Noman ul haq ${ }^{3}$.

${ }^{1}$ West Virginia University Health Sciences Centre, Morgantown, West Virginia, United States of America (Correspondence to: M Samsoor Zarak: samzarak@gmail.com). ${ }^{2}$ Bolan Medical College, Brewery Road, Quetta, Pakistan. ${ }^{3}$ Department of Pharmacy Practice, University of Balochistan, Quetta, Pakistan.

\begin{abstract}
Background: Typhoid fever is spread by ingestion of contaminated food or water, which is linked to infrastructure; specifically, sewage and sanitation. In developing countries, infrastructure varies according to socioeconomic status (SES). Balochistan is the least developed province of Pakistan.

Aims: To analyse the association between the clinical features of typhoid fever and socioeconomic status.

Methods: A quantitative, cross-sectional study was conducted in Quetta, Balochistan, Pakistan. Between May and October 2017, 143 patients presented to tertiary care hospitals and private clinics with a complaint of fever lasting $\sim 3$ days, along with a clinical history of headache, malaise, diarrhoea or constipation, abdominal pain, dry cough, and anorexia. All patients had a positive blood culture for Salmonella enterica serotype Typhi. Eighteen patients dropped out of the study, leaving 125.

Results: Seventy (56\%) participants had low socioeconomic status (SES), 40 (32\%) middle SES and 15( 12\%) high SES. The strongest predictors of presenting with typhoid fever were patients' clinical condition when presenting to health facilities, followed by SES. Most respondents had a treatment duration of 1-2 weeks. SES had a high impact on source of drinking water supply.

Conclusion: The strongest predictor of reporting typhoid fever was the current clinical condition of the patients, followed closely by SES. The incidence of typhoid fever in the low SES patients was almost the same as in the middle and high SES patients. Patients with low SES were more susceptible to contracting typhoid fever due to poor health status and facilities. Keywords: Balochistan, socioeconomic status, typhoid fever, enteric fever, Pakistan.

Citation: Samsoor Zarak M; Sana H; Shah M; Lehri S; Saghir M; Gul Q. et al. Association of clinical features of typhoid fever with socioeconomic status in Pakistan. East Mediterr Health J. 2021;27(11):1078-1083. https://doi.org/10.26719/emhj.21.054

Received: 25/09/19; accepted: 19/04/21

Copyright (C) World Health Organization (WHO) 2021. Open Access. Some rights reserved. This work is available under the CC BY-NC-SA 3.0 IGO license (https://creativecommons.org/licenses/by-nc-sa/3.o/igo)
\end{abstract}

\section{Introduction}

Typhoid fever is a severe illness caused primarily by Gram-negative Salmonella enterica serotype Typhi (1). It is indicated by nonspecific symptoms such as continuous fever, headache, nausea, poor appetite, lethargy, diarrhoea and sometimes constipation (2). Other clinical features include splenomegaly, hepatomegaly, rose spots, and lethal intestinal perforation (1). It is contracted via the faecal-oral route by ingestion of food or water contaminated with Salmonella species. Poor hygiene and sewage are considered to be contributing factors. The global burden of typhoid fever over the past few decades shows that there are 21.6 million cases globally and $\sim 216500$ deaths annually (3). The annual incidence of typhoid fever in Asia is $>100 / 100000$ cases (4). More than $90 \%$ of typhoid fever cases arise from South and Southeast Asia (3), mainly Pakistan, India, China, Indonesia and Viet Nam, where the disease is still considered to be endemic (4).

Pakistan is a developing country with a rapidly growing population and less than satisfactory water, food and hygiene measures that result in a flourishing habitat for infectious diseases. According to a study in
2013 in Quetta, 18.6\% of paediatric patients had positive serological tests for typhoid fever (5). In Karachi, the incidence of typhoid fever was 710/100 000 when diagnosed by serological tests, and almost 170/100 000 when diagnosed by blood culture (6).

Health issues are frequently related to socioeconomic status (SES), which serves as a reliable indicator of population mortality and morbidity (7). Most studies have shed light on health-related issues associated with low SES; mainly because individuals with low SES are more susceptible to illness and death compared with middle and high SES. Typhoid fever remains a poorly characterized disease, with uncertain and often inaccessible methods of diagnosis and lack of data about the total global burden (8). It is hard to understand the incidence and prevalence patterns of typhoid fever among the population due to its often random occurrence without much distinction for SES or age.

The present study is believed to be the first to analyse the association of typhoid fever and its clinical features, such as signs and symptoms, duration and treatment, with SES. 


\section{Methods}

\section{Study design and population}

This was a questionnaire-based quantitative, cross-sectional study conducted in Quetta, Balochistan, Pakistan. Between May and October 2017, 143 patients presented to tertiary care hospitals and private clinics with a complaint of fever lasting $\sim 3$ days, along with a clinical history of headache, malaise, diarrhoea or constipation, abdominal pain, dry cough, and anorexia. All patients had a positive blood culture for $S$. Typhi. Participants were interviewed and their answers were recorded. Eighteen patients dropped out of the study, leaving a total of 125 .

\section{Ethical considerations}

Informed consent was obtained from the patients for publication of this study at the time of interview. The study was reviewed by the Institutional Review Board of Bolan Medical College, Quetta.

\section{Study tool}

The study tool was a self-designed pro forma divided into 3 sections: (1) informed consent; (2) demographic characteristics of patients; and (3) questionnaire comprising 23 questions ( 6 on SES, 4 on personal hygiene and 13 on clinical aspects of typhoid fever). The first 9 questions had several options and only 1 was to be circled as an answer, whereas the last 14 required written statements.

\section{Data analysis}

The statistical analysis was done using SPSS version 20 . Statistical significance was determined by $\chi^{2}$ test and $P$ value (<0.05). A regression model was used to establish the association of clinical features of typhoid fever with SES.

\section{Results}

\section{Demographic characteristics}

Ninety-one patients $(72.8 \%)$ were aged $1-30$ years and 73 (58.4\%) were female (Table 1). Forty-six (36.8\%) patients were illiterate and $34(27.2 \%)$ were employed by the government on low wages. Fifty-six $(44.8 \%)$ patients belonged to nuclear families; $75(60 \%)$ owned their houses and $56(44.8 \%)$ had newly constructed cement rather than traditional mud houses.

\section{Water supply}

Most of the participants ( $n=92 ; 73.6 \%)$ used tap water for drinking and $33(26.4 \%)$ used filtered water.

\section{SES}

SES was based on a 2006 definition (9): low SES was an income of 4000-20 o0o Pakistani rupees (PKR); middle SES was 50 000-100 000 PKR; and high SES was > 100000 PKR. There were 70 (56\%) participants with low SES, 40 (32\%) with middle SES and $15(12 \%)$ with high SES.

\begin{tabular}{|c|c|c|}
\hline Demographic characteristics & $\begin{array}{c}\text { No. of } \\
\text { patients }\end{array}$ & Percentage \\
\hline \multicolumn{3}{|l|}{ Age (years) } \\
\hline $1-30$ & 91 & 72.8 \\
\hline $31-60$ & 30 & 24 \\
\hline $61-90$ & 4 & 3.2 \\
\hline \multicolumn{3}{|l|}{ Sex } \\
\hline Male & 52 & 41.6 \\
\hline Female & 73 & 58.4 \\
\hline \multicolumn{3}{|l|}{ Education } \\
\hline None & 46 & 36.8 \\
\hline High school or under & 51 & 40.8 \\
\hline Undergraduate & 17 & 13.6 \\
\hline Postgraduate & 11 & 8.8 \\
\hline \multicolumn{3}{|l|}{ Occupation } \\
\hline Government & 34 & 27.2 \\
\hline Student & 33 & 26.4 \\
\hline Labourer & 18 & 14.4 \\
\hline Business/landlord & 5 & 4.0 \\
\hline Housewife & 23 & 18.4 \\
\hline Not mentioned & 12 & 9.6 \\
\hline \multicolumn{3}{|l|}{ Type of family } \\
\hline Nuclear & 56 & 44.8 \\
\hline Extended & 42 & 33.6 \\
\hline Not mentioned & 27 & 21.6 \\
\hline \multicolumn{3}{|l|}{ House occupancy } \\
\hline Owned & 75 & 60.0 \\
\hline Rented & 43 & 34.4 \\
\hline Not mentioned & 7 & 5.6 \\
\hline \multicolumn{3}{|l|}{ House construction } \\
\hline Mud & 54 & 43.2 \\
\hline Cement & 56 & 44.8 \\
\hline Not mentioned & 15 & 12.0 \\
\hline
\end{tabular}

\section{Clinical features}

Most of the participants ( $\mathrm{n}=93 ; 74.4 \%$ ) had a first-time infection (Table 2). Ninety-four (75.2\%) reported improvement in their health after initiating treatment, and 91 (72.8\%) reported that duration of illness was $<1$ month. Forty-three (34.4\%) participants were prescribed a combination of antibiotics and analgesics, and 77 (61.6\%) used only cephalosporin. The duration of treatment for 101 $(80.8 \%)$ patients was $1-2$ weeks.

\section{Signs and symptoms}

Most of the patients presented with fever $(n=123 ; 98.4 \%)$, $112(89.6 \%)$ with nausea or vomiting, and 114 (91.2\%) with diarrhoea (Table 3).

\section{Typhoid fever and SES}

Most respondents had treatment duration of 1-2 weeks, which was significantly more likely in patients with low or middle SES $(\mathrm{P}=0.006)$ (Table 4). Unsatisfactory personal hygiene was significantly associated with low and middle SES $(\mathrm{P}=0.000)$. Eating outside was significantly more common in patients with low or middle SES $(\mathrm{P}=$ 0.008). Use of complementary medicine was significantly more common in patients with low or middle SES (P = o.006). 


\begin{tabular}{|c|c|c|}
\hline Clinical aspects & $\begin{array}{c}\text { No. of } \\
\text { patients }\end{array}$ & Percentage \\
\hline \multicolumn{3}{|l|}{ Type of infection } \\
\hline First time & 93 & 74.4 \\
\hline Relapse & 32 & 25.6 \\
\hline \multicolumn{3}{|l|}{ Current condition } \\
\hline Improved & 94 & 75.2 \\
\hline Not improved & 13 & 10.4 \\
\hline Uncertain & 18 & 14.4 \\
\hline \multicolumn{3}{|l|}{ Duration of disease } \\
\hline$<1$ month & 91 & 72.8 \\
\hline $1-3$ months & 27 & 21.6 \\
\hline 4-6 months & 1 & 0.8 \\
\hline $1-2$ years & 1 & 0.8 \\
\hline$>2$ years & 1 & 0.8 \\
\hline Uncertain & 4 & 3.2 \\
\hline \multicolumn{3}{|l|}{ Drugs } \\
\hline Antibiotic & 13 & 10.4 \\
\hline Antibiotic + analgesic & 43 & 34.4 \\
\hline Antibiotic + analgesic + antinausea & 19 & 15.2 \\
\hline Antibiotic + analgesic + antacid & 35 & 28.0 \\
\hline Antibiotic + analgesic + antinausea + & 7 & 5.6 \\
\hline antacid & 4 & 3.2 \\
\hline Antibiotic + antinausea & 4 & 3.2 \\
\hline Antibiotic + analgesic + antidiarrhoeal & & \\
\hline \multicolumn{3}{|l|}{ Antibiotics } \\
\hline Cephalosporin & 77 & 61.6 \\
\hline Quinolone & 19 & 15.2 \\
\hline Penicillin & 2 & 1.6 \\
\hline Other types & 4 & 3.2 \\
\hline Cephalosporin + quinolone & 7 & 5.6 \\
\hline Cephalosporin + penicillin & 2 & 1.6 \\
\hline Cephalosporin + any other & 10 & 8.0 \\
\hline Cephalosporin + quinolone + any other & 4 & 3.2 \\
\hline \multicolumn{3}{|l|}{ Duration of treatment } \\
\hline 1-14 days & 101 & 80.8 \\
\hline $15-28$ days & 10 & 8.0 \\
\hline$<1$ month & 13 & 10.4 \\
\hline Uncertain & 1 & 0.8 \\
\hline
\end{tabular}

Table 3 Signs and symptoms in patients with typhoid fever

\begin{tabular}{lcc} 
Complications & $\begin{array}{c}\text { No. of } \\
\text { patients }\end{array}$ & Percentage \\
Fever & & \\
Febrile & 123 & 98.4 \\
Nonfebrile & 2 & 1.6 \\
Pain & & \\
Headache & 23 & 18.4 \\
Abdominal pain & 37 & 29.6 \\
Body ache & 19 & 15.2 \\
Headache, body ache & 14 & 11.2 \\
Headache, abdominal pain & 11 & 8.8 \\
Body ache, abdominal pain & 18 & 14.4 \\
Headache, abdominal pain, body ache & 3 & 2.4 \\
Nausea/vomiting & & \\
Present & 112 & 89.6 \\
Absent & 13 & 10.4 \\
Diarrhoea/loose motion & & \\
Present & 114 & 91.2 \\
Absent & 11 & 8.8 \\
\hline
\end{tabular}

\section{Demographic factors associated with water supply in patients with typhoid fever}

Personal hygiene showed a significant association with the source of water supply $(P=0.000)$. Socioeconomic status SES also showed a significant association with source of water supply $(P=0.000)$.

\section{Regression analysis of association of SES and Clinical features of typhoid fever}

The strongest predictor of reporting typhoid fever was patients' current condition, with an odds ratio (OR) of 1.3 [95\% confidence interval (CI) 0.76-2.1] (Table 5). SES was the next strongest contributing factor (OR 1.2, 95\% CI 0.68-2.2). This indicated that patients who had typhoid fever were more likely to report signs and symptoms than those who did not have signs and symptoms, after controlling for all other factors in the model. The OR for infections was 0.87 , indicating that for every additional typhoid infection, respondents were 0.87 times less likely to report it, after controlling for other factors in the model.

\section{Discussion}

SES is a reliable indicator of morbidity and mortality, and serves as a predictor for society as a whole (10). Since the 19th century, a lot of work has been done to discover the relationship between social and health status. Multiple indicators are used to measure SES in a community, including occupation, education and income/wealth. To understand better the intricacies of SES, these indicators need to be considered all at once, along with others affecting the economic and living conditions of the population (11). Our study considered the dimension of income to classify SES in accordance with a detailed study conducted in 2006, defining the income groups in Pakistan (9). The dimensions of education and occupation were also included to gain a better understanding of the association.

We observed that most of the patients diagnosed with typhoid fever were aged 1-30 years, which confirmed previous findings (12), and $56 \%$ of the patients had low SES. It was also observed that $36.8 \%$ of patients were uneducated. Most of the patients were employed; however, their SES was not dictated by whether they were employed but rather by their income. Although patients with middle and high SES were diagnosed with typhoid fever, their comparatively better living conditions with regard to water and food supply, as well as their awareness of seeking timely medical attention, gave them a better chance of avoiding the disease and its consequences.

Most of the patients diagnosed with typhoid fever had unfiltered water supplies, which supports the fact that water and food sources are the most common methods of transmission (13). We also observed that people with high SES had mostly filtered water resources but nevertheless succumbed to the disease, indicating other risk factors 


\begin{tabular}{|c|c|c|c|c|}
\hline & \multicolumn{3}{|c|}{ Socioeconomic class } & \multirow[t]{2}{*}{$\boldsymbol{P}$} \\
\hline & High & Low & Middle & \\
\hline \multicolumn{5}{|l|}{ Disease duration } \\
\hline$><1$ month & 15 & 44 & 32 & 0.354 \\
\hline $1-3$ months & 0 & 20 & 7 & \\
\hline 4-6 months & 0 & 1 & 0 & \\
\hline 1-2 year & 0 & 1 & 0 & \\
\hline$>2$ years & 0 & 1 & 0 & \\
\hline Uncertain & 0 & 3 & 1 & \\
\hline \multicolumn{5}{|l|}{ Treatment duration } \\
\hline 1 day & 0 & 0 & 1 & 0.006 \\
\hline 2-3 days & 0 & 16 & 5 & \\
\hline 4-7 days & 0 & 11 & 3 & \\
\hline 1-2 weeks & 11 & 31 & 23 & \\
\hline 3-4 weeks & 4 & 1 & 5 & \\
\hline 1-2 month & 0 & 10 & 2 & \\
\hline$>2$ months & 0 & 1 & 0 & \\
\hline Uncertain & 0 & 0 & 1 & \\
\hline \multicolumn{5}{|l|}{ Personal hygiene } \\
\hline Satisfactory & 15 & 1 & 26 & 0.000 \\
\hline Not satisfactory & 0 & 69 & 14 & \\
\hline \multicolumn{5}{|l|}{ Habit of eating outside } \\
\hline Frequently & 13 & 29 & 26 & 0.008 \\
\hline Not likely & 2 & 20 & 8 & \\
\hline Failed to mention & 0 & 21 & 6 & \\
\hline \multicolumn{5}{|l|}{ Cause of treatment-seeking delay } \\
\hline Burden of studies & 0 & 0 & 2 & \\
\hline Failed to mention & 0 & 11 & 4 & 0.221 \\
\hline Lack of awareness & 0 & 3 & 1 & \\
\hline Lack of facilities & 0 & 7 & 1 & \\
\hline Misdiagnosed & 0 & 2 & 0 & \\
\hline None & 15 & 46 & 31 & \\
\hline Self-medication & 0 & 0 & 1 & \\
\hline Took a break because of pregnancy & 0 & 1 & 0 & \\
\hline \multicolumn{5}{|l|}{ Complementary medicine tried } \\
\hline Yes & 2 & 20 & 4 & 0.006 \\
\hline No & 12 & 29 & 29 & \\
\hline Failed to mention & 1 & 21 & 7 & \\
\hline
\end{tabular}

like food and hygiene practices. Cephalosporin was a popular choice of treatment, and in some cases, empirical therapy was undertaken to cure symptoms.

SES also had a significant effect on duration of treatment and was shorter in patients with high compared with middle or low SES. The duration of treatment for some patients with low or middle SES lasted for several months. This confirms the explanation that people with high SES have the awareness and basic facilities to seek early medical intervention. Furthermore, some participants had a considerable period of delay before seeking medical intervention. The most common reason besides lack of facilities was lack of awareness regarding the disease and its basic signs and symptoms.

\begin{tabular}{|c|c|c|c|}
\hline \multirow[t]{2}{*}{ Demographic factors } & \multicolumn{3}{|c|}{ Source of water supply } \\
\hline & Tap water & Filtered water & $P^{*}$ \\
\hline \multicolumn{4}{|l|}{ Hygienic practices } \\
\hline Satisfactory & 21 & 21 & 0.000 \\
\hline Not satisfactory & 71 & 12 & \\
\hline \multicolumn{4}{|l|}{ Eating habits } \\
\hline Healthy & 44 & 24 & 0.019 \\
\hline Unhealthy & 23 & 7 & \\
\hline Failed to mention & 25 & 2 & \\
\hline \multicolumn{4}{|l|}{ Socioeconomic status } \\
\hline High & 5 & 10 & 0.000 \\
\hline Low & 65 & 5 & \\
\hline Middle & 22 & 18 & \\
\hline
\end{tabular}


Patients, especially those with low SES, were in the habit of seeking treatment with complementary medicine.

SES played a significant role in patients' hygiene, indicating poor hygienic practice in those with low SES. Typhoid fever was most commonly observed in patients with low SES but it was also seen in those with high SES, which suggests that SES does not necessarily dictate the causative pattern of typhoid fever. Its occurrence in less-privileged people is understandable due to lack of education regarding the disease and collective poor living conditions and health facilities. The fact that typhoid fever affects the middle and high SES groups in roughly the same measure gives it a unique and confounding causative pattern.

The largest contributor to reporting a case of typhoid fever was the current condition of the patients, followed closely by SES. We also observed that patients who had typhoid fever were more likely to report signs and symptoms of the disease than were those who did not have signs and symptoms, after controlling for other factors in the model.

One limitation of the present study was that it was based on a small sample. Further research in a larger populationbased study may give better and more consistent results.

\section{Conclusion}

Typhoid fever remains one of the most poorly characterized diseases even today. This is mainly due to the lack of data on the global burden of the disease and controversies regarding the accuracy of the diagnostic tests, and lack of awareness in the general population. Our study concluded that the largest contributor to reporting typhoid fever was the current condition of the patients followed closely by SES. We showed that the incidence pattern of typhoid fever had no distinction for SES and the disease affected people with low SES in almost the same measure as those with middle and high SES. However, patients with low SES are more susceptible to contracting typhoid fever with more distressing signs, symptoms and disease duration due to meagre health education and facilities. There is a need for health professionals and the general population to address typhoid fever, prioritizing low and middle SES and poor health facilities, which pose a threat as great as multidrug-resistant bacteria.

Funding: None.

Competing interests: None declared.

\section{Lien entre le tableau clinique de la fièvre typhoïde et le statut socio-économique au Pakistan \\ Résumé}

Contexte : La fièvre typhoïde se propage par ingestion d'eau ou d'aliments contaminés, elle-même liée aux infrastructures, et plus particulièrement aux systèmes d'égout et d'assainissement de l'eau. Dans les pays en développement, les infrastructures varient en fonction du statut socio-économique. Le Baloutchistan est la province la moins développée du Pakistan.

Objectifs : Analyser le lien entre le tableau clinique de la fièvre typhoïde et le statut socio-économique des patients.

Méthodes : Une étude transversale quantitative a été menée à Quetta, au Baloutchistan (Pakistan). Entre mai et octobre 2017, 143 patients ont consulté dans des hôpitaux de soins tertiaires et des cliniques privées pour une fièvre qui persistait depuis environ trois jours, accompagnée d'antécédents cliniques de céphalées, de malaise, de diarrhée ou de constipation, de douleurs abdominales, de toux sèche et d'anorexie. Tous les patients présentaient une hémoculture positive pour la Salmonella enterica sérotype Typhi. Dix-huit patients ont quitté l'étude, qui s'est poursuivie avec les 125 restants.

Résultats : Soixante-dix participants (56\%) avaient un statut socio-économique faible, 40 (32\%) avaient un statut moyen et $15(12 \%)$ avaient un statut élevé. L'état clinique des patients lors de leur arrivée dans les établissements de santé, suivis par le statut socio-économique étaient les principaux facteurs prédictifs de consultation pour symptômes de fièvre typhoïde. La plupart des participants ont reçu un traitement dont la durée était d'une à deux semaines. Le statut socio-économique avait un impact important sur la source d'approvisionnement en eau potable.

Conclusion : Le principal facteur prédictif de déclaration de symptômes de fièvre typhoïde était l'état clinique des patients au moment de leur arrivée dans l'établissement de santé, suivi de près par le statut socio-économique. L'incidence de la fièvre typhoïde chez les patients de faible statut socio-économique était presque la même que chez les patients de statut moyen ou élevé. Les patients ayant un statut socio-économique faible étaient plus susceptibles de contracter la fièvre typhoïde en raison de leur mauvais état de santé et d'installations sanitaires médiocres. 


\section{الارتباط بين السمات السريرية لحمى التيفود والوضع الاجتهاعي والاقتصادي في باكستان \\ حممد سمسور زر اك، حمايال ثناء، مزّكان شاه، شبير لهري، ، ماهيكان صغير، قنديل جل، محمد سعود، عقيل نسيم، نعحان الحت}

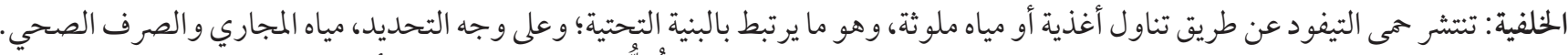

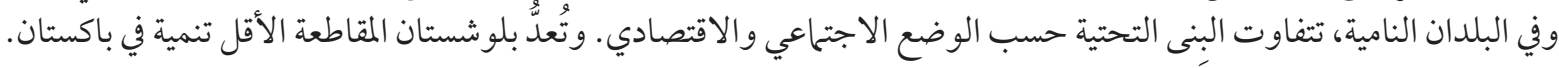
الأهداف: هدفت هذه الدراسة الم تحليل الارتباط بين السمات السريرية لحمى التيفود و الوضع الاجتماعي والاقتصادي.

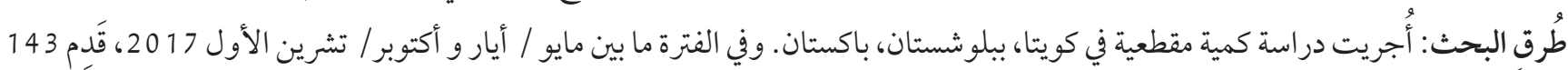

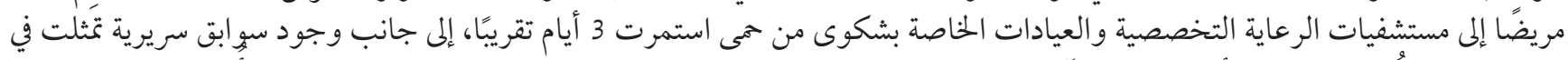

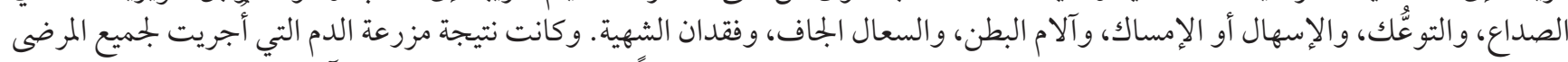

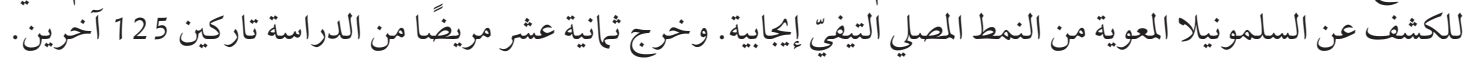

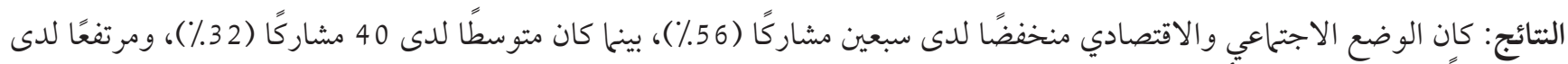

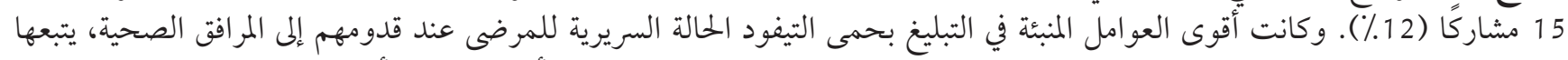

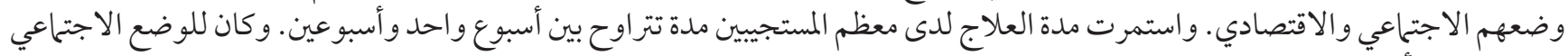

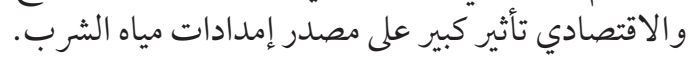

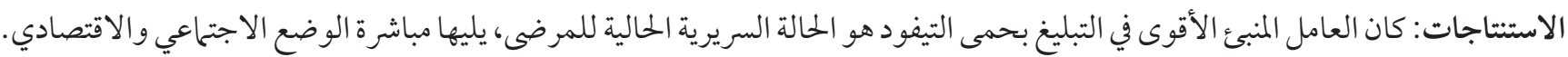

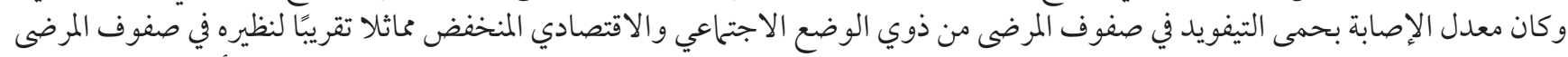

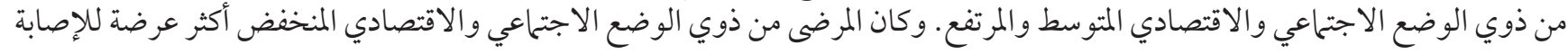

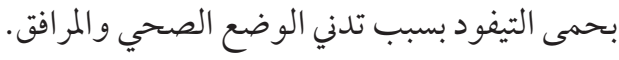

\section{References}

1. Hosoglu S, Aldemir M, Akalin S, Geyik MF, Tacyildiz IH, Loeb M. Risk factors for enteric perforation in patients with typhoid fever. Am J Epidemiol. 2004 Jul 1;160(1):46-50. https://doi.org/10.1093/aje/kwh172 PMID:15229116

2. Klotz SA, Jorgensen JH, Buckwold FJ, Craven PC. Typhoid fever: an epidemic with remarkably few clinical signs and symptoms. Arch Intern Med. 1984 Mar;144(3):533-7. https://doi.org/10.1001/archinte.144.3.533 PMID:6703825

3. Crump JA, Luby SP, Mintz ED. The global burden of typhoid fever. Bull World Health Organ. 2004 May;82(5):346-53. PMID:15298225

4. Ochiai RL, Acosta CJ, Danovaro-Holliday M, Baiqing D, Bhattacharya SK, Agtini MD, et al. A study of typhoid fever in five Asian countries: disease burden and implications for controls. Bull World Health Organ. 2008 Apr;86(4):260-8. https://doi.org/10.2471/ blt.06.039818 PMID:18438514

5. Khan MN, Shafee M, Hussain K, Samad A, Awan MA, Manan A, et al. Typhoid fever in paediatric patients in Quetta, Balochistan, Pakistan. Pak J Med Sci. 2013 Jul;29(4):929-32. https://doi.org/10.12669/pjms.294.3251 PMID:24353661

6. Siddiqui FJ, Rabbani F, Hasan R, Nizami SQ, Bhutta ZA. Typhoid fever in children: some epidemiological considerations from Karachi, Pakistan. Int J Infect Dis. 2006 May;10(3):215-22. https://doi.org/10.1016/j.ijid.2005.03.010 PMID:16431148

7. Feinstein JS. The relationship between socioeconomic status and health: a review of the literature. Milbank Q. 1993;71(2):279322. PMID:8510603

8. Crump J, Ram P, Gupta S, Miller M, Mintz E. Part I. Analysis of data gaps pertaining to Salmonella enterica serotype Typhi infections in low and medium human development index countries, 1984-2005. Epidemiol Infect. 2008 Apr;136(4):436-48. https://doi. org/10.1017/S0950268807009338 PMID:17686194

9. Subohi A. Defining income groups. Dawn. 20 November 2006 (https://www.dawn.com/news/219652/defining-income-groups, accessed 22 July 2021).

10. Winkleby MA, Jatulis DE, Frank E, Fortmann SP. Socioeconomic status and health: how education, income, and occupation contribute to risk factors for cardiovascular disease. Am J Public Health. 1992 Jun;82(6):816-20. https://doi.org/10.2105/ajph.82.6.816 PMID:1585961

11. Durkin MS, Islam S, Hasan Z, Zaman S. Measures of socioeconomic status for child health research: comparative results from Bangladesh and Pakistan. Soc Sci Med. 1994 May;38(9):1289-97. https://doi.org/10.1016/0277-9536(94)90192-9 PMID:8016692

12. Parry CM. Epidemiological and clinical aspects of human typhoid fever. Cambridge: Cambridge University Press; 2006.

13. Crump JA, Mintz ED. Global trends in typhoid and paratyphoid fever. Clin Infect Dis. 2010 Jan 15;50(2):241-6. https://doi. org/10.1086/649541 PMID:20014951 